\title{
The Scientific Basis of Tissue Transplantation
}


This page is intentionally left blank 


\title{
Aduances in Tissue Banking Vol. 5
}

\section{The Scientific Basis of Tissue Transplantation}

\author{
Editor-in-Chief \\ G O Phillips \\ Research Transfer Ltd, Cardiff, Wales, UK \\ Volume Editor \\ A Nather
}

National University Hospital Tissue Bank, Singapore

Regional Editors

D M Strong

Puget Sound Blood Center, USA

$\mathbf{R}$ von Versen (Europe)

German Institute for Cell and Tissue Replacement, Germany 


\section{Published by}

World Scientific Publishing Co. Pte. Ltd.

P O Box 128, Farrer Road, Singapore 912805

USA office: Suite 1B, 1060 Main Street, River Edge, NJ 07661

UK office: 57 Shelton Street, Covent Garden, London WC2H 9HE

\section{British Library Cataloguing-in-Publication Data}

A catalogue record for this book is available from the British Library.

\section{ADVANCES IN TISSUE BANKING (Vol.5)}

Copyright $\odot 2001$ by World Scientific Publishing Co. Pte. Ltd.

All rights reserved. This book, or parts thereof, may not be reproduced in any form or by any means, electronic or mechanical, including photocopying, recording or any information storage and retrieval system now known or to be invented, without written permission from the Publisher.

For photocopying of material in this volume, please pay a copying fee through the Copyright Clearance Center, Inc., 222 Rosewood Drive, Danvers, MA 01923, USA. In this case permission to photocopy is not required from the publisher.

ISBN 981-02-4583-1

Printed in Singapore by FuIsland Offset Printing 


\section{ADVANCES IN TISSUE BANKING}

\section{International Advisory Board}

H. Burchardt, USA
A. Gross, Canada
M. Itoman, Japan
J. Kearney, UK
J. Komender, Poland
B. Loty, France
P. Mericka, Czech Republic
D.A.F. Morgan, Australia
D. Pegg, UK
M. Salai, Israel
W.W. Tomford, USA
Y. Vajaradul, Thailand
H. Winkler, Austria
N. Yusof, Malaysia
N. Triantafyllou, Greece
R. Capanna, Italy
W.W. Boeckx, Belgium
C.J. Yim, Korea 
This page is intentionally left blank 


\section{LIST OF CONTRIBUTORS}

\section{JIRI ADLER}

Tissue Bank University Hospital

Brno, Czech Republic

\section{KENNETH M.C. CHEUNG}

Department of Orthopaedic Surgery

The University of Hong Kong

The Duchess of Kent Children's Hospital

12 Sandy Bay Road, Hong Kong

\section{JOHN CHIA}

Department of Orthopaedic Surgery

National University Hospital

Lower Kent Ridge Road, Singapore 119074

\section{LOUIS T.C. CHOW}

Department of Anatomical \& Cellular Pathology

The Chinese University of Hong Kong

Prince of Wales Hospital, Shatin, NT, Hong Kong, SAR

\section{KHAIRUL ZAMAN HAJI MOHD DAHLAN}

Radiation Processing Technology Division

Malaysian Institute for Nuclear Technology Research (MINT)

Bangi, 43000 Kajang, Selangor, Malaysia

\section{MALCOLM DAVIES}

Institute of Nephrology

University of Wales College of Medicine

Heath Park, Cardiff CF14 4XN, Wales, UK 


\section{MOHMOOD FARAZDAGHI}

International Federation of Eye Banks

Tissue Banks International, 815 Park Avenue

Baltimore, MD 21201, USA

\section{SAMEERA M. FARAZDAGHI}

Johns Hopkins University

Johns Hopkins School of Hygiene and Public Health

615 N Wolfe Street, Baltimore, MD 21205, USA

LINDA L.-K. FU

Musculoskeletal Tissue Bank

at Sir Y.K. Pao Centre for Cancer

The Chinese University of Hong Kong

Prince of Wales Hospital, Shatin, NT, Hong Kong, SAR

\section{JAMES GRIFFITH}

Department of Diagnostic Radiology \& Organ Imaging

The Chinese University of Hong Kong

Prince of Wales Hospital, Shatin, NT, Hong Kong, SAR

\section{HO KEE HAI}

Department of Oral and Maxillofacial Surgery

National University Hospital

Lower Kent Ridge Road, Singapore 119074

\section{N. HILMY}

Batan Research Tissue Bank

Centre for Research and Development of Isotopes

and Radiation Technology

National Nuclear Energy Agency of Indonesia

Jalan Cinere Ps. Jumat

P.O. Box 7002, Jakarta 12070 JKSKL

Indonesia 


\title{
CHARANJIT KAUR
}

Department of Anatomy, Faculty of Medicine

National University of Singapore

4 Medical Drive, MD10, Singapore 117597

\author{
JAN KOLLER \\ Ruzinov General Hospital \\ Centre for Burns and Reconstructive Surgery \\ Central Tissue Bank, Ruzinovka 6, 82606 Bratislava \\ Slovak Republic
}

GAMINI KUMARASINGHE

Division of Microbiology

Department of Laboratory Medicine

National University Hospital

5 Lower Kent Ridge Road, Singapore 119074

SHEKHAR M. KUMTA

Department of Orthopaedics \& Traumatology

The Chinese University of Hong Kong

Prince of Wales Hospital, Shatin, NT, Hong Kong, SAR

P.C. LEUNG

Department of Orthopaedics \& Traumatology

The Chinese University of Hong Kong

Prince of Wales Hospital, Shatin, NT, Hong Kong, SAR

M. LINA

Batan Research Tissue Bank

Centre for Research and Development of Isotopes and Radiation Technology

National Nuclear Energy Agency of Indonesia

Jalan Cinere Ps. Jumat

P.O. Box 7002, Jakarta 12070 JKSKL

Indonesia 
KEITH D.K. LUK

Department of Orthopaedic Surgery

The University of Hong Kong

The Duchess of Kent Children's Hospital

12 Sandy Bay Road, Hong Kong

\section{HASIM MOHAMAD}

Department of Surgery, Hospital Kota Bharu

155867 Kota Bharu, Kelantan, Malaysia

and

National Tissue Bank

Hospital University Sains Malaysia

Kubang Kerian, 16150 Kota Bharu, Kelantan, Malaysia

KEITH MOORE

Clinical Research Laboratory

Wound Management Division

Smith \& Nephew Medical Limited

Imperial House, Imperial Way

Newport, South Wales NP10 8UH, UK

\section{S.Z. MORDIFFI}

Major Operating Theatre Suite

Nursing Department, National University Hospital

5 Lower Kent Ridge Road, Singapore 119074

\section{AZIZ NATHER}

NUH Tissue Bank

National University Hospital

5 Lower Kent Ridge Road, Singapore 119074

\section{KAREN A. NELSON}

Puget Sound Blood Center

921 Terry Avenue, Seattle, WA 98104

USA 
BARRY P. PEREIRA

Department of Orthopaedic Surgery

National University Hospital

Lower Kent Ridge Road, Singapore 119074

\section{GLYN O. PHILLIPS}

Research Transfer Ltd

2 Plymouth Drive

Radyr, Cardiff CF15 8BL, UK

\section{JOSEPH THAMBIAH}

Department of Orthopaedic Surgery

National University Hospital

Lower Kent Ridge Road, Singapore 119074

\section{P. THIAGARAJAN}

Division of Adult Reconstructive Surgery

Department of Orthopaedic Surgery

National University Hospital

Lower Kent Ridge Road, Singapore 119074

\section{GARETH J. THOMAS}

Institute of Nephrology

University of Wales College of Medicine

Heath Park, Cardiff CF14 4XN, Wales, UK

M. YEGAPPAN

Division of Adult Reconstructive Surgery

Department of Orthopaedic Surgery

National University Hospital

Lower Kent Ridge Road, Singapore 119074 


\section{CHANG JOON YIM}

Dankook University School of Dentistry

Infirmary Dental Hospital and Dankook University Hospital

Department of Oral \& Maxillofacial Surgery

7-1 Sinbudong, Cheonan, 330-716, Republic of Korea

NORIMAH YUSOF

Tissue Bank

Malaysian Institute for Nuclear Technology Research (MINT)

Bangi, 43000 Kajang, Selangor, Malaysia 


\section{PREFACE}

This Preface need only be short, since the rationale and basis for the volume is given below in the Introduction. My objective now is to acknowledge the central role of Professor Aziz Nather in editing and planning this volume. As the Director of the International Atomic Energy Agency Training Courses in tissue banking at the Regional Centre at the National University Hospital in Singapore, he recognised the need for the tissue banker, not only to be well versed in the production techniques, but also in the scientific principles which underpin the entire subject. With such an interdisciplinary subject, access to the various scientific and medicallyrelated materials is often difficult for the student. In the one-year National University of Singapore University Diploma Course which he initiated, Prof. Nather, therefore, introduced lectures by specialists which covered these associated subjects. It then became even clearer that the student did not have access to appropriate texts to study the subject in more depth. Consequently, this volume was conceived. It now provides another building unit to give the tissue banker and tissue user a foundation to the subject. He is uniquely qualified to pilot this volume, for he himself is both a tissue banker and user, and additionally a pioneering educationalist in the subject. The product in this volume will prove valuable to all involved in tissue banking and provide a ready reference to the various scientific basic parts of the field. We must all thank him and congratulate him and his colleagues on the outcome.

Glyn O. Phillips Editor-in-Chief 
This page is intentionally left blank 


\section{CONTENTS}

List of Contributors

vii

Preface

xiii

Introduction

xix

Section I: Anatomy

Chapter 1 Anatomy of the Upper Limb

Chapter 2 Anatomy of the Lower Limb

Chapter 3 Anatomy of the Spine

Chapter 4 Anatomy of the Pelvis

Chapter 5 Anatomy of the Oral Maxillofacial Region

Section II: Matrix Biology and Physiology of Tissues

Chapter 6 The Organisation of the Extracellular Matrix

Chapter 7 Histology of Bone

Chapter 8 Histology of Cartilage

Chapter 9 Basic Anatomy and Physiology of Human Skin

Chapter 10 Anatomy and Embryology of Human Placenta, Amnion and Chorion

Chapter 11 Electron Microscopy of Human Amniotic Membrane 
Section III: Microbiology

Chapter 12 Introduction to Medical Microbiology

Chapter 13 Bioburden Estimation in Relation to Sterilisation

Chapter 14 Transmissible Diseases of Particular Importance in the Immunocompromised and Transplant Recipients

Section IV: Sterile Techniques

Chapter 15 Principles of Sterile Technique

Chapter 16 Sterile Procurement of Bones and Ligaments

Chapter 17 Sterile Preparation of Tissue Grafts During Transplantation

Section V: Radiation Sciences

Chapter 18 Radiation Sciences

Chapter 19 Effect of Radiation on Microorganisms Mechanism of Radiation Sterilisation

Chapter 20 Effects of Ionising Radiation on Viruses, Proteins and Prions

Section VI: Biology of Healing of Allografts

Chapter 21 The Scientific Basis of Wound Healing

Chapter 22 Skin and Amnion Grafts 398

Chapter 23 The Role of BMP in Bone Incorporation

Chapter 24 Biology of Healing of Large Deep-Frozen Cortical Bone Allografts 
Chapter 25 The Biology of Massive Bone Allografts:

Understanding Allograft Biology

and Adapting it Towards Successful

Clinical Application

Chapter 26 Effect of Growth Factors on Healing and the Clinical Applications of Autogenous Platelet Rich Plasma Gel to Enhance Bone Formation

Chapter 27 Biology and Biomechanics of Anterior Cruciate Ligament Allograft Reconstruction

Section VII: Biomechanics of Allografts

Chapter 28 Some Principles of Biomechanics Structural and Material Properties

Chapter 29 Biomechanics of Bone Allograft Transplantation

Section VIII: Immunology

Chapter 30 Basic Principles of Transplantation Immunology

Subject Index 
This page is intentionally left blank 


\section{INTRODUCTION}

\section{AZIZ NATHER and GLYN O. PHILLIPS}

\section{Background}

The International Atomic Energy Agency (IAEA) through its programme "Radiation Sterilisation of Tissue Grafts", produced a distance learning package on the procedures involved in tissue banking, particularly in the application of radiation to sterilise tissues (Nather, 1999a; 1999b; Phillips and Strong, 1999; Nather, 2000a; 2000b; Phillips, 2000). The individual modules are: 0 - Historical Background; 1 -Rules and Regulations; 2-Organisation; 3 Quality Assurance; 4-Procurement; 5-Processing; 6-Distribution \& Utilisation; 7 - Future Developments in Tissue Banking. This curriculum has been used extensively throughout the Asia Pacific region itself, and in other regions such as Latin America, Africa and parts of Europe.

The IAEA draft curriculum was first piloted in Singapore during the IAEA/RCA Workshop on Tissue Banking in September 1995. Consequently, IAEA established a Regional Training Centre in the National University Hospital, Singapore to train tissue bank operators in the Asia Pacific region using the curriculum. Since then, the training centre has conducted several distance learning programmes for tissue-bank operators in the region.

To enable this development to proceed effectively, the Singapore Government (Ministry of Environment) provided a grant to the NUH Tissue Bank through the National Science and Technology Board to develop the centre to be equipped with facilities for hands-on training. This grant also provided for sufficient funds to convert the draft curriculum into a multimedia curriculum. The National 
University Hospital provided the space in which the NUH Tissue Bank was constructed. Both NUH and NUS contributed renovation funds for the building of a purpose-built tissue bank with a reception area, documentation room, wet processing and dry processing laboratories as well as a library for resource materials in tissue procurement and processing, and in tissue transplantation.

Simultaneously, the National University of Singapore (NUS) approved the development of a one-year distance learning Diploma Course in Tissue Banking to be conducted by the NUH Tissue Bank at the NUS Training Centre. The syllabus for the Diploma Course basically consisted of three components: the multimedia curriculum on tissue banking, a basic sciences component and a recommended textbook - the book selected being the series Advances in Tissue Banking. With these three components together, a comprehensive training could be provided.

With funds from the Singapore Government in April 1998, a multimedia element could be introduced. This required further editing of text from draft to module and the editing of illustrative materials into video demonstrations of not more than 30 minutes each. Special box containers were designed to house each module to include a booklet, accompanying videotapes and illustrative case slides from the region and available reference texts. With the first module, an audiocassette was introduced with instructions on how to use the distance learning package. The complete package - seven box containers in all, was distributed to all tissue banks in the Asia Pacific member states. In April 1998, a "Train the Trainers" workshop was held in Singapore to instruct the national trainers on the use of multimedia curriculum. Since then, this multimedia curriculum has replaced the draft curriculum as the first component of the syllabus for the Diploma Course.

The University Diploma Course is conducted over a period of one-year. First, the trainees attend a face-to-face two-week intensive training course in Singapore. Over the subsequent year, they are given progressive study of the curriculum, guided by National Coordinators. Over this period, they pursue a number of practical and written assignments which are then remitted to the University 
for assessment. Finally, at the end of the year, they return to Singapore for the final examination. The overall diploma is awarded by continuous assessment over the entire one-year course.

Development has continued regularly. The seven videotapes have now been converted into two compact discs contained in a jewel case. The curriculum has been in great demand. The initial 100 sets produced were quickly exhausted. Therefore, another 250 sets were produced in April 2000. The multimedia curriculum package has been further redesigned to have all the seven module booklets conveniently housed in one specially printed box container, which contains the seven modules, two compact discs, an audiocassette and a new updated textbook as a companion volume to the multimedia curriculum. This new compact design makes the distribution of the curriculum more convenient. The updated volume Radiation and Tissue Banking (2000) was written by experts contracted by IAEA and printed with funds from the Singapore Government. It is an appropriate companion volume to the IAEA multimedia curriculum. It was released in July 2000 and provided free of charge to tissue banks in the member states throughout the world.

\section{The Present Development}

The basic sciences component of the syllabus for the Diploma Course, which is presented in the training course, includes subjects such as Anatomy, Matrix Biology and Physiology of Tissues, Microbiology, Sterile Techniques, Radiation Sciences, Biology of Healing of Allografts, Biomechanics of Allografts and Immunology. It was quickly realised that students found difficulty in obtaining basic text for this part of the Diploma Course curriculum. Available specialist textbooks on the diverse subjects addressed, such as Anatomy, Microbiology, Immunology etc., were too detailed to meet the needs of the Diploma students. It was therefore decided to produce a specifically-designed specialist textbook incorporating the various topics and to be directed at the appropriate level so as to address the specific needs of the Diploma Course students and generally that of the tissue banker, tissue procurer, tissue processer 
and tissue transplanter. This textbook is written with this objective in mind. Authors were selected to write the various chapters, with specific instructions to address the needs of tissue-bank operators.

\section{Section I: Anatomy}

Tissue bankers need to have a basic knowledge of anatomy of the various regions ranging from the upper limb, lower limb, spine, pelvis to the maxillo-facial region. Several tissue-bank operators without a medical background will find this section especially useful when carrying out their daily work. Personnel with a medical background will also find this section a joy to read, rather than having to access detailed texts from anatomy textbooks since no textbook of anatomy for tissue-bank operators exists. Technologists too can now understand better the anatomy of the tissues they have been procuring or processing, and also the types of tissues that could be used for different anatomical regions.

\section{Section II: Matrix Biology \& Physiology of Tissues}

The microscopic structure of tissues are detailed in this section, starting with the extracellular matrix, bone, cartilage, skin and amnion. Again, the major attractive feature is its descriptive nature with excellent illustrations. Worthy of mention is a special chapter on electron microscopy of the amnion, a tissue widely used in the Asia Pacific region.

\section{Section III: Microbiology}

Microbiology is a very important subject for tissue bankers and tissue transplant surgeons alike. The basic concepts in medical microbiology are carefully explained. Bioburden estimation itself merits one whole chapter. Equally important is the knowledge of the various transmissible diseases. Tissue bankers seek to maintain a high quality control standard to ensure safe tissue transplantation practice. No 
efforts must be spared to prevent possible disease transmission during tissue transplantation. It is therefore important that tissuebank operators have a good knowledge of the seriousness of these diseases, including AIDS, Hepatitis B and C, and syphilis.

\section{Section IV: Sterile Techniques}

To achieve high quality control standards, tissue procurement should be performed as far as possible under sterile conditions. One whole chapter is devoted to the principles of aseptic technique from scrubbing techniques, monitoring of sterility in the operating room to methods of sterilisation of equipment and materials. Another chapter is devoted to procuring tissues under sterile conditions and a third chapter to ensuring that the tissues transplanted are prepared in the correct aseptic manner so as to avoid the much dreaded complication of infection. Again, excellent illustrations have been used to make the text more readable and easier to understand.

\section{Section V: Radiation Sciences}

This section contains chapters written by three radiation scientists. The basic principles of radiation sciences are presented in the first chapter with good illustrations, so that technologists with medical background and no training in the radiation sciences can better appreciate the principles of ionising radiations. The second chapter deals with the effect of radiation on microorganisms and the third the effect of radiation on viruses, proteins and prions.

\section{Section VI: Biology of Healing of Allografts}

The biology of the healing of tissues is described, starting from the scientific basis of wound healing to the healing of the skin and amnion, and the healing of bones and ligaments. The role of various growth factors, including bone morphogenetic proteins and plateletderived growth factor to promote bone healing, is also described and discussed in greater detail. 
This section is important to surgeons who use allografts and who need to understand how the transplanted tissues heal so that they can choose more wisely the right type of graft for the various clinical conditions they encounter. In this way, better results can be obtained and complications minimised. Similarly, tissue bankers who prepare the tissue grafts will also better understand the functions of the various types of tissues they process.

\section{Section VII: Biomechanics of Allografts}

The first chapter is written by a mechanical engineer to introduce the basic concepts of biomechanics, and which could be readily understood by the tissue-bank technologists. Ample illustrations have been used to make this section user-friendly. In another chapter, the structural requirements of bone allografts for the various reconstructions performed are described by an orthopaedic surgeon, covering deep-frozen cortical bone allografts for massive allograft reconstruction of lower limbs requiring weight-bearing functions, the adequacy of lyophilised cortical allografts for massive spine reconstruction and the adequacy of lyophilised morsellised bone allografts for packing cavities in bones.

\section{Section VIII: Immunology}

This last section, written by an immunologist, outlines the basic principles of the immunology of tissue transplantation. This is vital both for the end-users (surgeons), using the bone allografts to avoid the dreaded complication of immune rejection and resulting infection and for the tissue-bank operators who need to process the tissue grafts to eliminate as much as possible any immunogenic properties of the tissue graft products.

\section{References}

NATHER, A. (1999a). Tissue banking in Asia Pacific region - The Asia Pacific Association of Surgical Tissue Banking. In: Advances 
in Tissue Banking, Vol. 3, G.O. Phillips, R. von Versen, M. Strong and A. Nather, eds., World Scientific, Singapore, pp. 419-425.

NATHER, A. (1999b). Tissue Banking in the Asia Pacific region: current status and future developments, J. Orthop. Surg. 7(2), 8993.

NATHER, A. (2000a). Diploma training for technologists in tissue banking, Cell And Tissue Banking 1(1), 41-44.

NATHER, A. (2000b). Tissue banking in Asia Pacific region - Ethical, legal, religious, cultural and other regulatory aspects, J. ASEAN Orthop. Assoc. 13(1), 60-63.

PHILLIPS, G.O. (2000). The future role of the International Atomic Energy Agency (IAEA), Cell and Tissue Banking 1, 27-40.

PHILLIPS G.O. and STRONG D.M. (1999). The contribution of the International Atomic Energy Agency (IAEA) to tissue banking. In: Advances in Tissue Banking, Vol. 3, G.O. Phillips, R. von Versen, M. Strong and A. Nather, eds., World Scientific, Singapore, pp. $403-417$. 